\title{
Stratigraphy of the Gulneri Formation (Upper Cretaceous) in the Type Section, Dokan Area, Northeastern Iraq
}

\author{
Tarik S. Abawi \\ Department of Geology \\ College of Science \\ Mosul University
}

\author{
Rund A. Hammoudi \\ Department of Geology \\ College of Science \\ Mosul University
}

\author{
Araz O. Al-Khafaf \\ Department of Geology \\ College of Sience \\ Sulaimaniya University
}

(Received 11/6/2006, Accepted 30/8/2006)

\begin{abstract}
Eight planktonic and six benthonic foraminiferal species were recorded from the type section of the Gulneri Formation at the site of Dokan Dam, Dokan area, northeastern Iraq. The sediments of the Gulneri Formation consist basically of organic-carbon rich black shale and represent a record of the ocean anoxic event 2 (OAE2) across the Cenomanian-Turonian boundary. The planktonic foraminiferal assemblages of the Gulneri Formation indicates an Early Turonian age for the formation .

\section{طبلفية تكون كولنيري (الكربتلم لاعل)في القطلع المونجي -مطاقة دوكل - ششملشرق العرق}

\section{المالغص}

سجل تولجد ^ انواع من الفورلمنيفرا الطافية و 7 أنواع من الفورلمنفرا القاعي ـة ض من تك ـوين

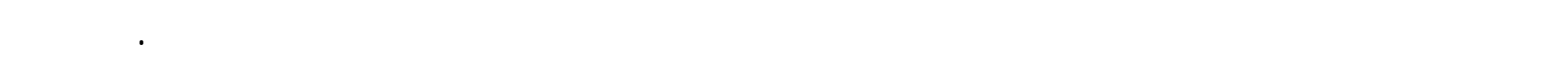

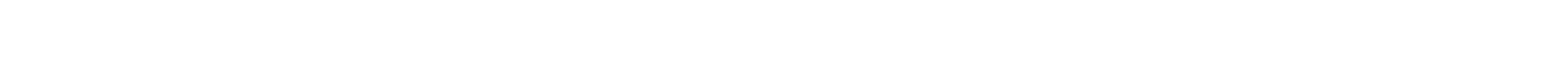
لحداث لستنزف الاوكسجين في البحار عبر الحد الفاطل بين للسنومانيان والتورونيلن ـ حدد عمر تكوين كولنيري في المقع قيد الدس بالتورونيلن المبكر .

\section{INTRODUCTION}

The Gulneri Formation was first described by Lancaster Jones in 1957 ( Bellen et al., 1959) from the site of the Dokan Dam in the High Folded Zone in northeastern Iraq. According to the original description, the formation is 1.1 to $1.2 \mathrm{~m}$ thick, consists of black, bituminous, finely laminated, calcareous shale with some glauconite and collophane in the lower part and should be of Early Turonian age. Bellen et al., (1959) reported the following fossils from the Gulneri Formation in its type section : Rotalipora cf. appenninica Renz, Globotruncana helvetica Bolli, minute globigerinids, gumbelinids, fish detritus indet, small bicarinate Globotruncana spp.
\end{abstract}


According to Buday (1980) the Gulneri Formation represents the sediments of a relict sea that existed between the regression in the Cenomanian and the transgression in the Turonian. Buday (1980) stated that the depositional basin of the Gulneri Formation was euxenic based on the evidence of the high bitumen content and the dwarfing of the fossils .

Abawi and Hammoudi (1997) studied the foraminiferal biostratigraphy of the Gulneri Formation in Kirkuk area and assigned it to Late Turonian age .

According to Abawi and Mahmood (2005) the Gulneri Formation in Jambour well no. 46 (northern Iraq) is Middle to Late Turonian in age .

The present paper intends to give an account of the stratigraphy, the foraminiferal fauna and the paleoenvironment of the Gulneri Formation as exposed in the type section at the site of the Dokan Dam, northeastern Iraq (Fig . 1)

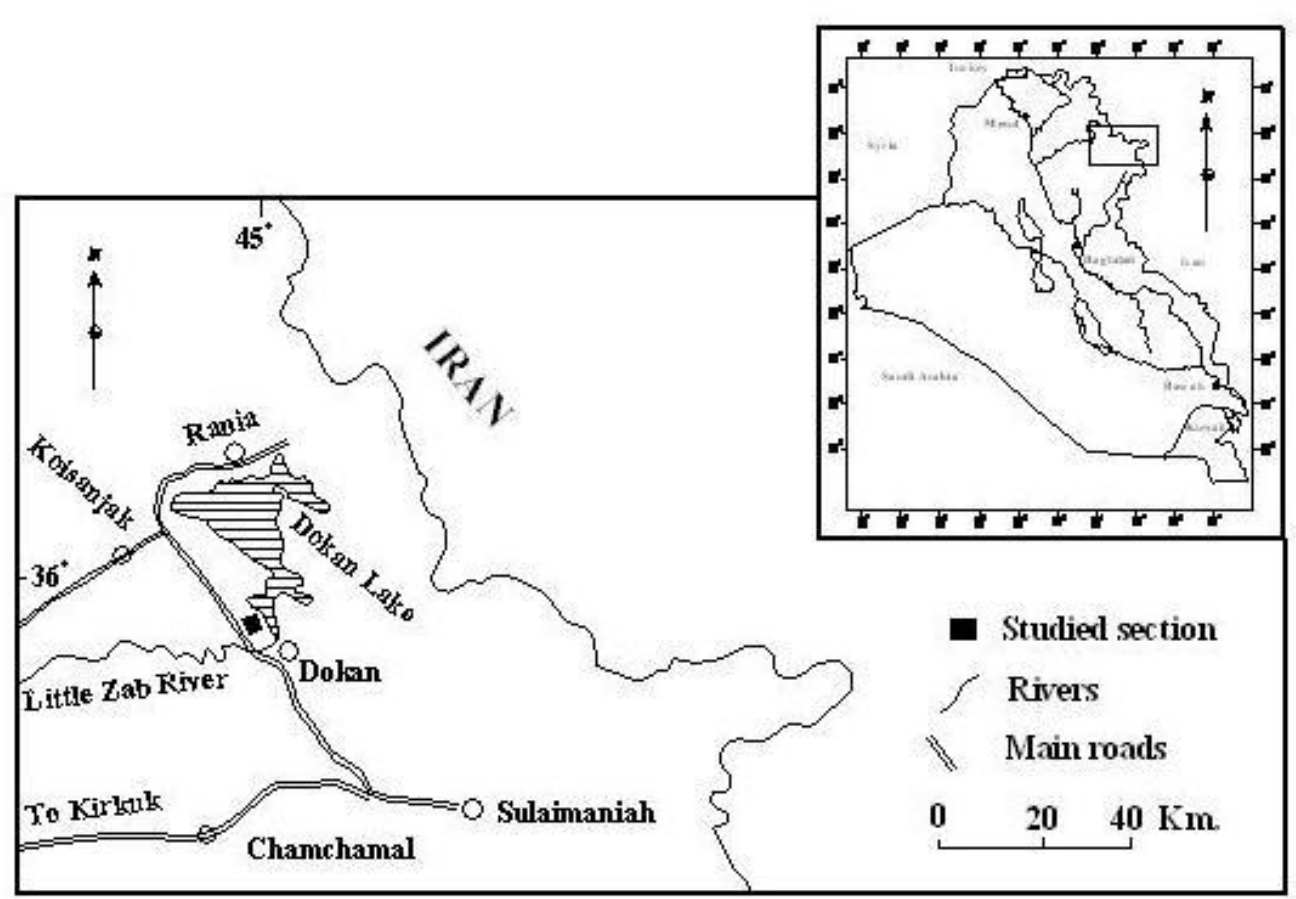

Fig.1: Location map

\section{LITHOSTRATIGRAPHY}

This investigation is based on material from the type section of the Gulneri Formation exposed about $200 \mathrm{~m}$ west of Dokan Dam , northeastern Iraq, at latitude 768,400 N and longitude 659, $860 \mathrm{E}$. In the studied section the Gulneri Formation is 1.75 $\mathrm{m}$ thick and unconformably underlain by the Dokan Formation of Cenomanian age and also unconformably overlain by the Kometan Formation of Middle Turonian-Early Campanian age (Fig. 2) . 


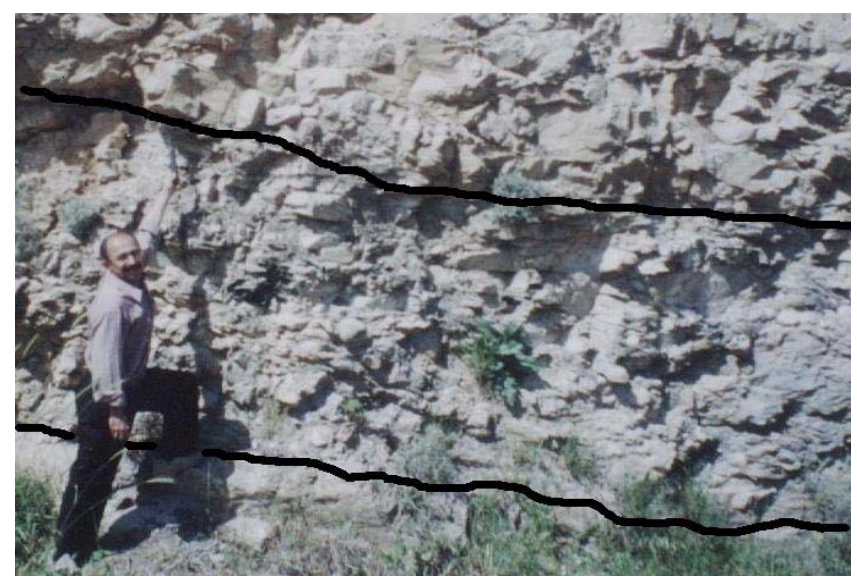

Fig. 2 :Gulneri Formation as exposed in the type section northeastern Iraq . Lower and upper boundaries of the formation are marked with black lines .

Seven rock samples were collected, at intervals ranging between $15-35 \mathrm{~cm}$, from the studied section. Lithologically, the Gulneri Formation in the investigated outcrop is composed basically of black, organic-carbon rich, finely laminated shale. The lower part of the section is characterized by the occurrence of glauconite and limestone boulders . These limestone boulders are derived from the underlying Dokan Formation and they represent an oligosteginal limestone containing rich planktonic foraminiferal fauna.

Washed materials and thin sections from the collected samples were investigated with regard to their fossils content and microfacies.

Petrographic investigation of the studied material reveals that the sediments of the Gulneri Formation are mainly represented by two microfacies units following the classification of Dunham (1962) ; these are :

Mudstone microfacies ,

Foraminiferal wackestone microfacies .

A detailed measured section of the Gulneri Formation with a brief description of the lithology and location of the samples is presented in Fig. (3).

\section{FORAMINIFERAL FAUNA}

The Gulneri Formation in the study area yielded a relatively low diversified foraminiferal assemblage showing common abundance of individuals. The individuals are usually dwarfish; this is due to unfavorable environmental conditions of low oxygen sea water. Washed samples of the investigated material show badly preserved and corroded specimens. The occurrence of the foraminiferal fauna is almost restricted to the middle and upper parts of the formation, whereas the lower part of the formation is nearly barren.

Eight planktonic foraminiferal species belonging to four genera were recorded from the studied section. The heterohelicids dominated the faunal assemblages. The recorded species are: Globigerinelloides ultramicra (Subbotina), Hedbergella delrioensis (Carsey ) , Hedbergella planispira (Tappan), Heterohelix moremani (Cushman), Heterohelix reussi 


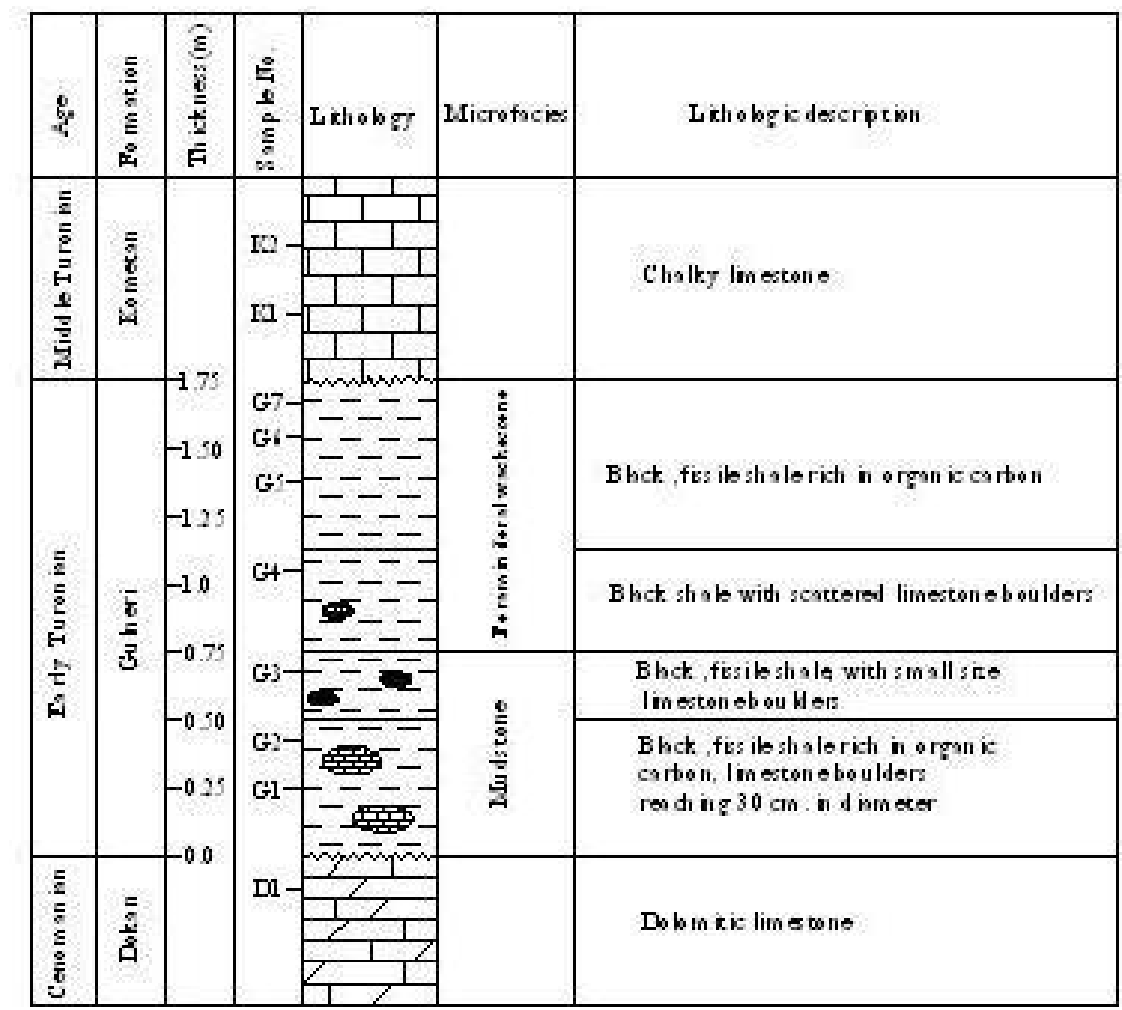

Fig.3: Stratigraphic columnar section of the Guheri Vertical scale Formation, type sec tion,Dokan Area, northeastern Iraq. $[0.50 \mathrm{~m}$.
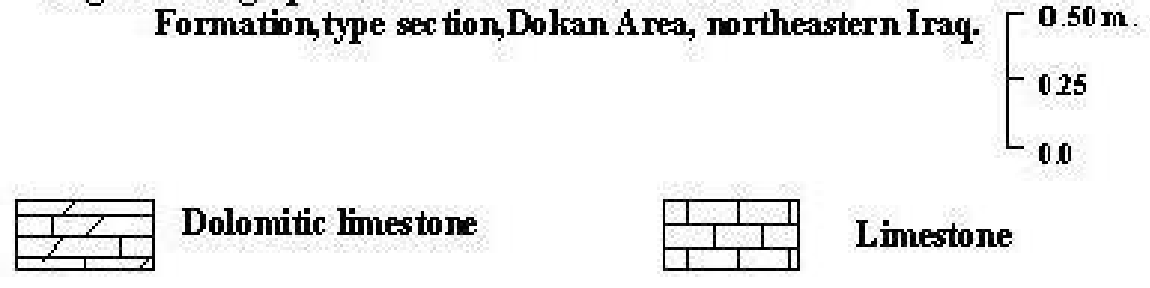

Dolomitic limestone

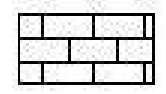

Limestone

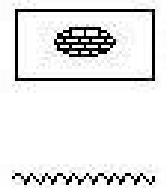

Limestone boulders derived

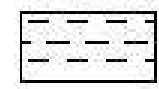

Shale

\section{Unc onfounity}

Fig. 3 : Stratigraphic Columnar Section of the Gulneri Formation, Type Section, Dokan Area, Northeastern Iraq.

(Cushman), Whiteinella archaeocretacea Pessagno, Whiteinella baltica Dougals and Rankin, Whiteinella inornata (Bolli).

In addition to above mentioned planktonic foraminifera the following benthonic foraminifera were identified: Dorothia cf. bulletta (Carsey), Gaudryina sp., Gavelinella cf. baltica Brotzen, Lagena sp., Lenticulina sp., Silicosigmoilina sp. The genus Silicosigmoilina Cushman and Church, (1929) is recorded for the first time from Iraq.

Investigation of thin section from the Dokan limestone boulders included in the Gulneri shale showed well preserved, abundant and well diversified microfauna (see appendix -1). 


\section{AGE DETERMINATION}

In spite of the low diversification of the foraminiferal fauna recorded from the Gulneri Formation, an accurate age determination of the formation could be obtained. Following the planktonic foraminiferal zonal scheme of Keller and Pardo (2004), see Fig. (4), the occurrence of Whiteinella archaeocretacea above the last occurrence of Rotalipora cushmani (Morrow) and below the first appearance of Helvetoglobotruncana helvetica (Bolli) represents the $W$. archaeocretacea Zone of latest Cenomanian - Early Turonian age. $R$. cushmani is not recorded in the Gulneri shale. Nevertheless thin sections of the Dokan limestone boulders, included in the Gulneri shale, show occurrence of Rotalipora spp., (see appendix 1). Hence the occurrence of Rotalipora cf. appenninica Renz, which is registered by Bellen et al. (1959) within the fossil assemblage of the Gulneri Formation , is actually derived from the limestone boulders .

\begin{tabular}{|c|c|c|c|c|c|c|c|c|}
\hline \multicolumn{5}{|c|}{ Keller \& Pardo , 2004} & \multicolumn{4}{|c|}{ Present Study } \\
\hline Age & \multicolumn{2}{|c|}{ Zonation } & \multicolumn{2}{|r|}{ Datum events } & \multicolumn{2}{|c|}{ Zonation } & Formation & Age \\
\hline క్ & \multicolumn{2}{|c|}{ H helvetica } & A & \multirow{2}{*}{ H. helvetica } & \multicolumn{2}{|c|}{ H. he wetica } & & 霹 \\
\hline है & \multicolumn{2}{|c|}{ ฐู้ $\begin{array}{l}\text { Heterohelix } \\
\text { moremani }\end{array}$} & & & \multirow{3}{*}{ 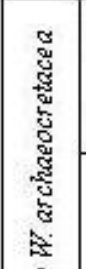 } & \multirow{2}{*}{ 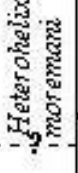 } & Guhneri & 密 \\
\hline \multirow{2}{*}{ 䗡 } & है & & & Heterohelix shiff & & & \multirow[b]{2}{*}{ Dokan } & \multirow{3}{*}{ 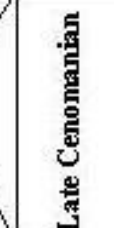 } \\
\hline & है & G. bentonensis & $y$ & G. bentonensis & & & & \\
\hline 5 & & oushmani & & R. cushmani & & & & \\
\hline
\end{tabular}

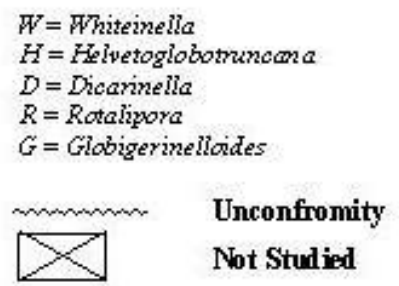

Fig.4: Correlation of the present zonal scheme with that of Keller \& Pardo,2004.

Fig. 4 : Correlation of the Present Zonal Scheme that of Keller and Pardo, 2004. 
Helvetoglobotruncana helvetica is first recorded in this study immediately above the Gulneri / Kometan contact within the lowermost part of the Kometan Formation. Hence the present occurrence of $W$. archaeocretacea in this study represents the W.archaeocretacea Zone according to Keller and Pardo (op.cit,). The abundant occurrence of the heterohelicids in the studied samples indicates the Heterohelix moremani Subzone of latest Cenomanian to Early Turonian age (Keller and Prado, 2004). The occurrence of Whiteinella inornata in the studied material, which ranges from Early Turonian to Santonian (see Caron, 1985), excludes pre-Turonian age for the present formation. Accordingly the sediments of the Gulneri Formation in its type section are Early Turonian in age .

\section{PALEOENVIRONMENT}

Marine strata rich in organic-carbon (black shale) deposited during the Cretaceous , representing oceanic anoxic events (OAE) has been discussed by many authors (Schlanger and Jenkyns, 1976; Jenkyns, 1980; Sliter, 1989) . According to Schlanger and Jenkyns (1976) these oceanic anoxia resulted from widespread and expanded oxygen minimum zones linked to transgressive sea-level pulses and the reduced oxygenation of oceanic bottom water leading to deposition of organic-carbon rich black shale. Schlanger and Jenkyns (op.cit.) mentioned two ocean anoxic events during the Cretaceous, the longterm Late Barremian-Albian (OAE1) and the short-term Cenomanian-Turonian (OAE2) events. According to Schlanger et al., 1987 (Cited in Sliter, 1989), the CenomanianTuronian maxima of organic-carbon burial occurs mainly within a single planktonic foraminiferal zone, the Whiteinella archaeocretacea Zone.

It is obvious that the Gulneri section in the study area represents a sedimentary record of the oceanic anoxia across the Cenomanian - Turonian Boundary (OAE2). This fact is evident by the organic-carbon rich black shale that comprises the lithology of the Gulneri Formation. The dominance of the heterohelicids within the planktonic foraminiferal fauna of the Gulneri Formation indicates a low oxygen marine environment. According to Keller and Pardo (2004), heterohelicids thrived in low oxygen marine environments with well-developed oxygen minimum zone. The low diversified and dwarfish benthonic fauna of the Gulneri Formation also indicates unfavorable conditions of anoxic bottom water . According to Lamolda and Peryt (1995); Peryt and Lamolda (1996), the faunas from the oxygen minimum zone are characterized by low diversity and small size

\section{CONCLUSION}

Sediments of the Gulneri Formation in the type area near Dokan, northeastern Iraq yielded low diversified foraminiferal fauna. The recognition of the Heterohelix moremani Subzone within the Whiteinella archaeocretacea Zone revels Early Turonian age for the Gulneri Formation in the study area. The Gulneri sediments represent a record of the ocean anoxic event 2 across the Cenomanian-Turonian Boundary; this is evident by the low diversified and dwarfish foraminiferal fauna, the dominant occurrence of the low oxygen tolerant heterohelicids and the organic-carbon rich black shale of the Gulneri Formation.

\section{ACKNOWLEDGEMENT}

The authors wish to express their gratitude to Dr. Fadhil Lawa and Mr. Azad Omer Ibrahim from the Dept. of Geology, University of Sulaimania for their field guidance. 


\section{REFERENCES}

Abawi, T.S. and Hammoudi, R.A., 1997. Foraminiferal Biostratigraphy of the Kometan and Gulneri Formations (Upper Cretaceous) in Kirkuk Area, North of Iraq. Jour. Geol. Soc. Iraq, Vol. 30, No. 2, pp.139-146.

Abawi, T.S. and Mahmood, S.A., 2005. Biostratigraphy of the Kometan and Gulneri Formations (Upper Cretaceous) in Jambur Well No.46, Northern Iraq. Iraqi Jour. Earth Sci., Vol. 5, No. 1, pp.1-8.

Bellen, R.C., Van Dunnington, H.V., Wetzel, R. and Morton, D., 1959, Lexique Stratigraphique International . Asie, Iraq, Vol. 3, No. 10a, 333p.

Buday, T., 1980. Stratigraphy and Paleogeography, In: Kassab, I.I.M. and Jassim, S.Z. (eds.): The Regional Geology of Iraq. SOM (D.G.Geol.Sur.Min.Invest.) Baghdad, V. 1, 445p.

Caron, M., 1985. Cretaceous Planktic Foraminifera, In: Bolli, H.M., Saunders, J.R. and Perch-Nielsen, K. (eds.): Plankton Stratigraphy . Cambridge Univ. Press, pp.17-86.

Dunham, R.J., 1962. Classification of Carbonate Rocks According to Depositional Texture, In: Ham, W.E. (ed.) Classification of Carbonate Rocks. Amer. Ass. Petrol. Geol. Bull.,Vol. 1, pp.108-121.

Jenkyns, H.C., 1980. Cretaceous Anoxic Events: From Continents to Ocean. Geol. Soc. London Jour.,Vol. 137, pp.171-188.

Keller, G. and Pardo, A., 2004. Age and Paleoenvironment of the Cenomanian-Turonian Global Stratotype Section and Point at Pueblo. Colorado, Marine Micropaleontology,Vol. 51, pp.95-128.

Lamolda, M.A. and Peryt, D., 1995. Benthonic Foraminifera Response to the Cenomanian-Turonian Boundary Event in the Ganuza Section, Northern Spain. Revista Espanola de Paleontologia , pp.101-118 .

Peryt, D. and Lamolda, M.A., 1996. Benthonic Foraminiferal Mass Extinction and Survival Assemblage from the Cenomanian-Turonian Boundary Event in the Menoyo Section, Northern Spain, In: Hart, M.B. (ed.) Biotic recovery from mass extinction events.Geological Survey Special Publication,Vol. 102, pp.245-258.

Schlanger, S.O. and Jenkyns, H.C., 1976. Cretaceous Oceanic Anoxic Events: Causes and Consequences. Geologie en Mijnbouw,Vol. 55, pp.179-184.

Sliter, W.V., 1989. Aptian Anoxia in the Pacific Basin. Geology,Vol. 17, pp. 909-912. 
Appendix -1 : Microfauna recorded from Dokan limestone boulders included in the Gulneri shale :

1- Calcispheres

2- Planktonic foraminifera :

Globigerinelloides ultramicra (Subbotina)

Clavihedbergella simplex (Morrow)

Hedbergella delrioensis (Carsey)

Hedbergella planispira (Tappan)

Heterhelix moremani (Cushman)

Rotalipora brotzeni (Sigal)

Rotalipora cushmani (Morrow)

Rotalipora greenhornensis (Morrow)

Rotalipora montsalvensis Mornod

Schackoina cenomana (Schacko)

Whiteinella archaeocretacea Pessagno

Whiteinella baltica Douglas and Rankin

Whiteinella paradubia (Sigal)

3- Benthonic foraminifera:

Lenticulina sp.

Nodosaria sp. 


\section{Plate No.1}

1- Whiteinella archaeocretacea Pessagno, equatorial section, Sample no.G 6, X100.

2-Heterohelix moremani (Cushman), Sample no. G 6, X100.

3-Foraminiferal wackestone microfacies of Gulneri Formation, Sample no.G 6, X60.

4-Silicosigmoilina sp., Sample no. G 4, X70.

5-Mudstone microfacies of Gulneri Formation, Sample no. G 3 , X50.

6-Foraminiferal wackestone microfacies of Gulneri Formation showing abundant heterohelicids . Sample no. G 6 , X60.

7-Dorothia cf. bulletta (Carsey), Sample no. G4, X70.

8-Oligosteginal limestone of Dokan boulders included in sample no. G 1, X70.

9- Whiteinella archeaeocretacea Pessagno, from Dokan boulder included in sample no. G 1 , axial secrion, $\mathrm{X} 80$.

10-Gavelinella cf. baltica Brotzen, umbilical side . Sample no. G 4 , X100.

11-Rotalipora cushmani (Morrow), from Dokan boulders included in sample no. G 2 , X80

12-Hedbergella delrioensis (Carsey), equatorial section, Sample no. G 6 , X 90.

13- Rotalipora brotzeni (Sigal), from Dokan boulders included in sample no. G 2, axial section . X80.

14-Whiteinella baltica Douglas and Rankin. Umbilical side, Sample no.G 6 ,X100.

15-Whiteinella inornata (Bolli), umbilical side. Sample no. G 4, X100.

16-Whiteinella inornata ( Bolli), spiral side. Sample no. G 4. X100.

17-Gaudryina sp., Sample no. G 4, X60.

18-Rotalipora greenhornensis (Morrow), from Dokan boulders included in sample no. G 2 , axial section , X80. 
Tarik S. Abawi et al.,

Plate No. 1
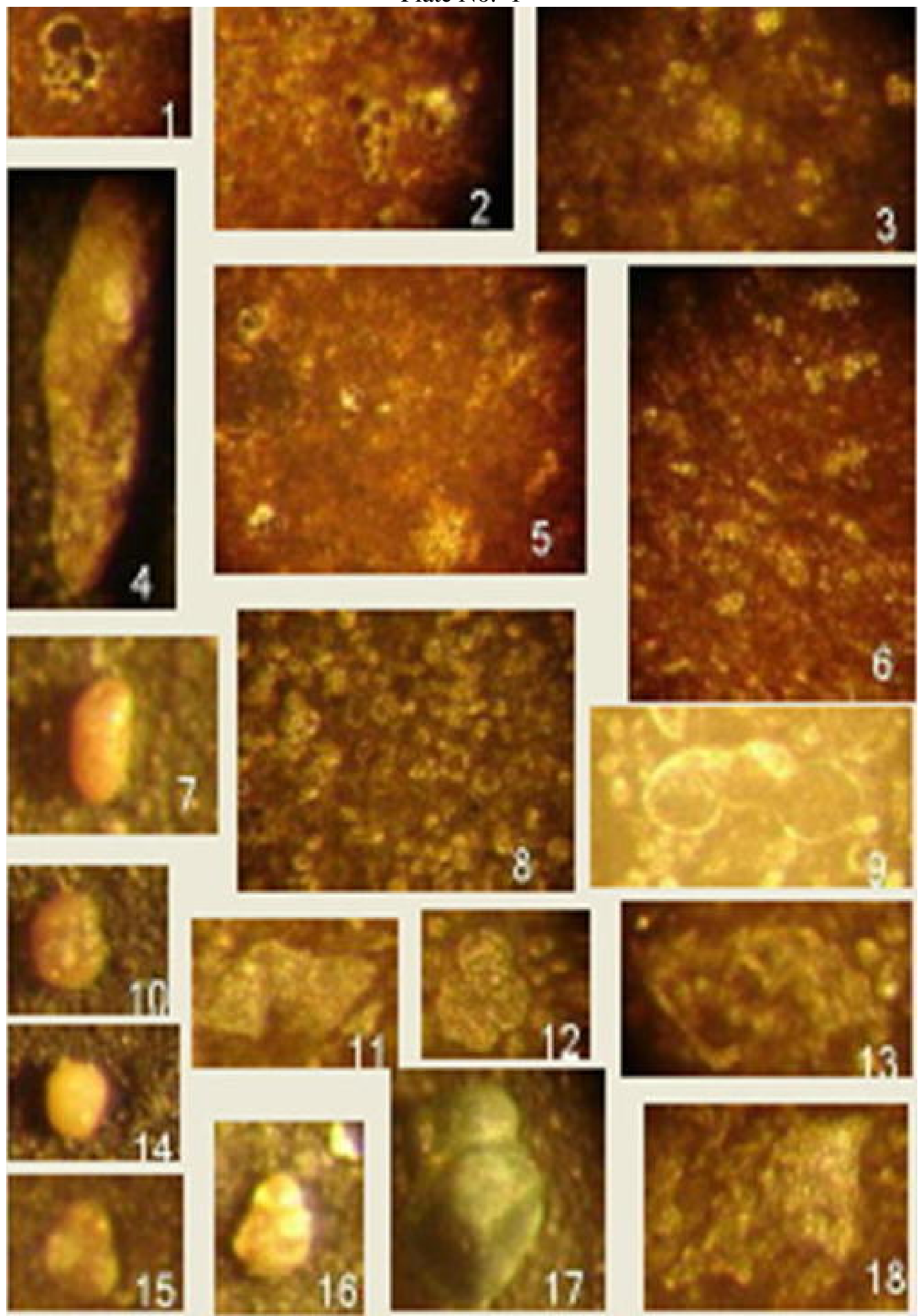